\title{
O DISPOSITIVO MORALITÚRGICO EM UMA ESCOLA PÚBLICA BRASILEIRA
}

\author{
Graciela Bernardi Horn ${ }^{1}$ \\ Rochele De Quadros Loguercio ${ }^{2}$
}

\begin{abstract}
RESUMO: A articulação observada entre vários elementos (sons, coisas, palavras, ações) em uma escola pública localizada no sul do Brasil foi o que vimos operando em jogos de saber/poder como uma malha curricular. Essa malha é composta por minuciosas, exegéticas e heterogêneas técnicas que, com valores morais cristãos, fabrica e dá visibilidade a um determinado modo de existência escolar cristã engendrada por procedimento pedagógico-litúrgico. Com o conceito de dispositivo de Foucault, procuramos ensaiar um exercício filosófico criador, produzindo um novo conceito, o dispositivo moralitúrgico, como ferramenta analítica. O movimento moral e litúrgico da pedagogia desse dispositivo convoca os indivíduos a, em atitude ascética, examinarem-se e corrigirem-se.
\end{abstract}

Palavras-chave: Dispositivo. Cristianismo. Subjetividade. Currículo. Escola.

\section{THE MORALITURGICAL DEVICE IN A BRAZILIAN PUBLIC SCHOOL}

\begin{abstract}
The articulation observed between various elements (sounds, things, words, actions) in a public school located in the south of Brazil was what we have seen operating in games of knowledge/power as a curriculum. This mesh is composed of meticulous, exegetical, and heterogeneous techniques that, with Christian moral values, fabricates and gives visibility to a certain mode of existence, that is, a Christian school subjectivity engineered by pedagogicalliturgical procedure. With the concept of Foucault's device, we tried to rehearse a creative philosophical exercise, producing a new concept, the moraliturgical device, as an analytical tool. The moral and liturgical movement of the pedagogy of this device calls on individuals, in an ascetic attitude, to examine and correct themselves.
\end{abstract}

Keywords: Device. Christianity. Subjectivity. Curriculum. School.

Este artigo é oriundo da tese de doutorado intitulada O Dispositivo Moralitúrgico em uma Escola Pública Brasileira, desenvolvida no Programa de Pós-graduação em Educação em Ciências da Universidade Federal do Rio Grande do Sul e financiada pela Coordenação de Aperfeiçoamento de Pessoal de Nível Superior.

1.Universidade Federal do Rio Grande do Sul - Programa de Pós-graduação em Educação em Ciências - Porto Alegre (RS), Brasil. E-mail: gracihorn@gmail.com

2.Universidade Federal do Rio Grande do Sul - Programa de Pós-graduação em Educação em Ciências - Porto Alegre (RS), Brasil. E-mail: rochelel@gmail.com

Editor de Seção:Antonio Alvaro Soares Zuin 


\title{
EL DISPOSITIVO MORALITURGICO EN UNA ESCUELA PUBLICA BRASILEÑA
}

\begin{abstract}
RESUMEN: La articulación observada entre varios elementos (sonidos, cosas, palabras, acciones) en una escuela pública ubicada al sur de Brasil fue lo que vimos operando en juegos de saber/poder como una malla curricular. Esa malla es compuesta por técnicas meticulosas, exegéticas y heterogéneas que, con valores morales cristianos, fabrica y da visibilidad a un cierto modo de existencia escolar cristiana generada por un procedimiento pedagógico-litúrgico. Con el concepto del dispositivo de Foucault, intentamos ensayar un ejercicio filosófico creativo, produciendo un nuevo concepto, el dispositivo moralitúrgico, como herramienta analítica. El movimiento moral y litúrgico de la pedagogía de este dispositivo convoca a los individuos, en una actitud ascética, a examinarse y corregirse.
\end{abstract}

Palabras-clave: Dispositivo. Cristianismo. Subjetividad. Currículo. Escuela.

\section{Introdução}

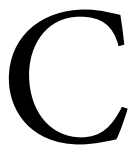

omo uma rede constituída por múltiplos e heterogêneos elementos (sons, coisas, palavras, ações etc.) funciona como produtora de verdade em uma escola? Como essa malha subjetiva o corpo escolar? A partir da perspectiva pós-estruturalista, tomamos esses questionamentos como propulsores deste trabalho, que considera o currículo escolar uma construção derivada de um campo de luta em que diferentes forças tentam estabelecer sua hegemonia. Consideramos, também, que o currículo que circula em uma dada escola é efeito produzido por diferentes forças que disputam quais verdades devem ser legitimadas e invaginadas em processos de subjetivação. Debruçamo-nos, assim, em analisar como funciona a articulação entre os elementos de uma escola para pensar como funciona esse processo.

Com o conceito/ferramenta "dispositivo", ${ }^{1}$ buscamos analisar como a rede constituída por múltiplos e díspares elementos ${ }^{2}$ funciona como engrenagem que ensina uma determinada forma de ver, pensar e falar moralcristianamente. ${ }^{3}$ Então, como exercício filosófico criador, com olhar foucaultiano, produzimos um conceito operador, o dispositivo moralitúrgico, como ferramenta analítica que busca estabelecer ressonâncias entre a moral e as liturgias cristãs constitutivas de uma malha estratégica envolvida em processos de subjetivação cristã em uma escola pública brasileira. Esse trabalho objetiva mostrar como uma rede de elementos dispostos estrategicamente na instituição está articulada de maneira a capturar os sentidos (visuais, auditivos, táteis) para que um determinado modo de vida moral e litúrgico seja aprendido e incorporado como princípio organizativo de um $\hat{e}^{t}$ hos ${ }^{4}$ cristão.

Partindo do entendimento de que o dispositivo produz subjetivações (ABADÍA, 2003; AGAMBEN, 2005), buscamos analisar como se estabelece o processo que configura certo modo de constituição de si, isto é, de relacionar-se consigo e com os outros a partir da flexão ou curvatura de um tipo de feixe de forças ${ }^{5}$ em múltiplas linhas que se enredam, relacionam-se em jogos de saber/poder e gestam a construção de determinados modos de ser e existir no mundo. Esses jogos engendram tudo o que pode ser dito em certos tempo e lugar, assim como a viabilidade de existência de um espaço passível de ser ocupado por um sujeito que fala e exerce determinadas funções (como por exemplo, a função docente de observar, interrogar, registrar e avaliar seus alunos). 


\section{Local do Estudo e Modo de Fazer a Pesquisa}

Isolada entre vales, a população da pequena localidade rural (uma mistura de açorianos, alemães e italianos) é cercada pelos morros da Serra Geral, no extremo norte do estado do Rio Grande do Sul. Comunidades rurais, em incipiente formação no início do século XVIII, organizaram rudimentares escolas engajadas em atividades unificadoras regidas por moral e costumes cristãos derivados da Europa (SILVA, 1985). Em meio ao mundo desconhecido e inseguro de colônias recém-formadas, "instituições como igreja, a escola e a família tinham a função de manter vivos os laços de origem através da religião, da língua e da ancestralidade comum" (VALDUGA, 2008, p. 19-20). As colônias eram espaços estrangeiros dentro do Brasil, que, talvez, vissem no cristianismo o ponto que congregava afinidades e sentimentos de solidariedade uns com os outros (VALDUGA, 2008).

A escola analisada neste artigo (e a pequena comunidade onde se insere) pinça alguns elementos do passado para torná-los próximos à contemporaneidade. O modo de vida baseado na agricultura familiar (suplantando a vegetação nativa para dar lugar a monoculturas de banana, maracujá, milho, cana, hortifrúti e eucalipto) e o vigor do cristianismo, por exemplo, são justificados na região como tradições culturais herdadas. Os moradores e escolares da localidade deste trabalho mostram forte orgulho em falar de sua descendência europeia, assim como em justificar a força do cristianismo na região como uma "tradição cultural" passada de modo fluido e difuso de geração para geração, característica marcante da pequena comunidade que os une como uma só família. De fato, olhos azuis, cabelos loiros e pele branca avermelhada com sardas constituem características fenotípicas da maioria dos escolares, assim como os sobrenomes que aparecem repetidamente nas listas da chamada escolar.

De março a setembro de 2017, passei a visitar a escola com regularidade - uma ou duas vezes por semana, durante toda a manhã e/ou a tarde, o que tornou minha presença corriqueira, para acompanhar as aulas de todas as turmas e disciplinas. A escola tem aproximadamente noventa alunos e um total de treze funcionárias mulheres (nove professoras, uma diretora e uma vice-diretora, uma merendeira e uma servente). É uma escola do campo, com turmas multisseriadas, o que significa que o ensino é ministrado, na mesma sala de aula, para várias séries do Ensino Fundamental simultaneamente (educação infantil, séries iniciais e finais), com alunos de idades e níveis de conhecimento diferentes. Essa escola é uma instituição pública que, apesar de pertencer a um Estado laico, é do tipo confessional, uma vez que o ensino está balizado por princípios e valores cristãos - com prejuízo de visões ateístas, agnósticas ou de religiões mais incipientes na esfera sócio-política.

Foram realizadas entrevistas semi-estruturadas (seis questões que abordaram a constituição do currículo e a relação com o espaço escolar e os conteúdos das diferentes disciplinas) com cinco professoras e quatro alunos que aceitaram conversar, sob Consentimento Livre e Esclarecido, com a gravação de suas falas. Os registros foram realizados privadamente, na sala dos professores, em horários com menos barulho e que interferissem o menos possível nas atividades dos entrevistados. Todos os tipos de registros mantiveram o anonimato dos componentes do corpo escolar.

O estudo, de cunho etnográfico, demandou um pertencimento ao local - o que implica discrição -, mas também uma "homocromia" em relação ao espaço, isto é, não ser saliente nem estranha demais ao corpo escolar. O modo de fazer a pesquisa se aproxima da bricolagem (LÉVI-STRAUSS, 1989), tipo de investigação que, sem instrumentos profissionais e roteiros preexistentes, recolhe e coleciona fragmentos heteróclitos de sígnos, cujo conjunto forma algo diferente do que se fossem considerados individualmente. É um processo de colecionar pequenos registros (por meio da fotografia, anotações em caderno de campo, entrevistas e imersão no campo de estudo), mesmo que, num primeiro momento, sejam considerados sem sentido. Então, 
um conjunto de objetos, palavras, sujeitos, arquiteturas etc. foi conformando uma nuvem heterogênea de elementos que se encaixaram uns nos outros, cujo movimento construiu os sentidos que fomos atribuindo à constituição do currículo da escola em questão.

Ao longo dos dias de observação, olhamos a forma como os espaços falam sobre determinado modo de organização escolar e, entendendo aquilo que alguns autores dizem a respeito da não neutralidade dos espaços, uma vez que constituem parte operante de um dispositivo que faz ver e fazer determinadas coisas, esfumaçando outras (FOUCAULT, 2013; FRAGO, ESCOLANO, 2001), fomos mapeando e agrupando certas falas, palavras, pessoas, enfim, o conjunto de coisas que constituem práticas que organizam determinada forma de vida em determinado espaço institucional. Então, um conjunto de objetos, palavras, sujeitos, arquiteturas, documentos etc. foi conformando uma nuvem heteróclita de elementos que, parecendo se encaixar uns nos outros, saltaram aos nossos olhos, primeiramente causando certo estranhamento e, após, configurando certo sentido. Algumas falas dos alunos e das professoras reverberaram em cânone junto aos demais elementos constitutivos do conjunto que passamos a enxergar e ao qual passamos a agregar cada vez mais elementos heterogêneos, cujo movimento, como num caleidoscópio, fez com que passassem a funcionar juntos. A reincidência de falas, ações, palavras, coisas etc. que capturaram nossa atenção mostra a saliência de determinada discursividade a ocupar e se tornar visível em um espaço.

Assim, estivemos atentas a olhar como o entrelaçamento dos elementos funcionou como práticas acionadas ou interditadas a partir de um saber cristão-pedagógico. Da imensa quantidade de elementos que constituem o currículo, vimos apenas um conjunto saltar, emergir, sair da planície e se elevar como relevo mais robusto. O relevo criado, ou conjunto-nuvem, caracteriza práticas que subjetivam os sujeitos escolares sobre como devem pensar e agir. Então, com o problema visto - uma rede de elementos concatenados, cujo conjunto organiza e subjetiva os escolares conforme a moral cristã -, criamos o conceito/ferramenta dispositivo moralitúrgico, para demarcar essa análise, qual seja: o funcionamento de um conjunto de elementos que constituem um dispositivo curricular produtor de subjetividade cristã escolar num espaço escolar público.

\section{Ferramentas Utilizadas}

É importante localizar os termos moral e liturgia no vocabulário foucaultiano, uma vez que tomamos seus conceitos como ferramentais para pensar nos problemas. Foucault, em História da Sexualidade 2, problematiza algumas oções que cercam a palavra "moral", fazendo algumas distinções. Por moral, entende-se um conjunto de valores e regras de conduta proposto a indivíduos e grupos por meio de diversas instituições (familiar, educativa, religiosa etc.). Esses valores e regras constituem um conjunto prescritivo chamado "código moral", que pode ou deve ser explicitamente ensinado ou transmitido de modo difuso, em um complexo jogo de elementos "que se compensam, se corrigem, se anulam em certos pontos, permitindo, assim, compromissos ou escapatórias" (FOUCAULT, 2001, p. 26). O autor distingue a moral da moralidade, sendo essa última considerada a maneira como o comportamento dos indivíduos/grupos se conduz em relação às regras e aos valores: ou seja, como se submetem/obedecem/respeitam ou resistem/ negligenciam a interdições, prescrições ou valores desse código. A isso, Foucault chama "moralidade dos comportamentos".

A noção de liturgia, embora não trabalhada por Foucault, é também potente à análise a que nos propomos para mostrar uma das técnicas do dispositivo moralitúrgico. A técnica litúrgica do dispositivo é o movimento, com cadência repetitiva, que regula e orienta o corpo escolar a exercer práticas redundantes e disciplinadoras de si em torno dos elementos que capturam e envolvem atenção/pensamento/corpo. 
A palavra liturgia designa um conjunto de gestos, palavras, ações e atitudes rotineiras que periodicamente se repetem, sucedem-se, intercambiam-se e organizam e dão determinada ordem à vida. $\mathrm{O}$ lugar onde ocorrem movimentos litúrgicos não é neutro, pois sons, gestos, cheiros, figuras e objetos convocam nossos sentidos a se comportar de determinada maneira e não de outra: algumas vezes, o local exige uma "roupa apropriada" ou "certa postura (evitar conversas paralelas, manter uma postura física adequada, realizar os gestos rituais propostos sobriamente)" (LORENZETTI, 2012, p. 12). No âmbito religioso cristão, a liturgia envolve: orações, cantos, confissões, leituras bíblicas, o ficar em pé, o juntar as mãos, ouvir, silenciar; todo um conjunto de elementos, formas, uma determinada estrutura (ADAM, 2010).

Desse modo, a liturgia desse dispositivo moralitúrgico disciplina e organiza - dentro dos vetores espacial/temporal que funcionam mutuamente implicados - a conduta dos corpos em um espaço escolar fechado, vigiado e que obedece a uma sequência de eventos que se repetem ao longo do tempo. A liturgia, como um jogo, implica rotinas e ritmos que convidam os alunos à sensação de pertencimento a algo cujas regras são cumpridas a fim de que o jogo possa ter continuidade. Mesmo aquele aluno que mostra dificuldades em aprender os conteúdos escolares entra no jogo disciplinar litúrgico, pois nele encontra certos conforto e aceitação perante os olhos vigilantes da escola, que o conduz a uma moralidade específica. Esse movimento litúrgico constitui uma tecnologia de $s i,{ }^{6}$ isto é, um jogo repetitivo em que se deve aprender as regras e a discernir "quem são os participantes para si mesmos e quem é cada um para os outros" (LARROSA, 1994, p. 45). O dispositivo moralitúrgico é mobilizado por uma engrenagem pedagógica, litúrgica e moral.

\section{Dispositivo Moralitúrgico e a Escola}

As instituições públicas brasileiras, na contemporaneidade, não são ateístas nem teocráticas, mas regidas por um arranjo político em que o Estado regula as manifestações religiosas em espaços públicos de uma sociedade (GIUMBELLI, 2014). Na Educação, a Lei de Diretrizes e Bases da Educação Nacional (LDB; Lei n. 9.394, de 20 de dezembro de 1996) estabelece, em seu artigo 33, que o ensino religioso é de matrícula facultativa e deve assegurar o respeito à diversidade cultural e religiosa do Brasil, vedadas quaisquer formas de proselitismo.

Apesar disso, o que vimos em nosso campo de pesquisa foi a presença hegemônica do cristianinsmo transbordando para todo o espaço escolar desse pequeno município. ${ }^{7}$ A rede traçada pelo dispositivo moralitúrgico é composta por elementos dispostos em profusão (como crucifixos e quadros de parede com imagens de Jesus Cristo, orações, sinal da cruz, confissão, presença do padre, filmes religiosos, parceria da escola com a igreja em atividades diversas, frases cristãs escritas nas paredes ou em cartazes, igreja/ cemitério, ${ }^{8}$ cantorias, palavras, sons e documentos), que se aproximam e dialogam harmonicamente entre si formando uma protuberância, ou seja, uma saliência evidenciada pelo dispositivo. Constituído por uma miríade de elementos diversos, essa maquinaria põe, em litúrgico movimento, os corpos escolares a falarem em nome de uma engrenagem que regula e é regulada por práticas discursivas/não discursivas, ${ }^{9}$ as quais instituem a repetição redundante disciplinadora de condutas. Por isso, esse é um dispositivo litúrgico e moral, uma vez que, de modo cirúrgico, tem função estratégica de construir uma fisiologia dos sujeitos escolares, incitando-os a questionarem, fiscalizarem, espreitarem, vigiarem a si e aos outros balizados pela moral cristã.

Estudantes são convocados a confeccionar cartazes, desenhos e textos com apelos cristãos e tais trabalhos, que, por vezes, "decoram" as paredes, são efeito de uma tecnologia pedagógica ${ }^{10}$ produtora de subjetividade cristã. Tal processo, balizado pela moral cristã, vai se conformando com/em mensagens cristãs 
pulverizadas no espaço (nas paredes com palavras ou frases de chamadas a homenagens religiosas cristãs ou frases de efeito moral) em vocabulário escolar/cristão que eventualmente se misturam.

O emaranhado de elementos funciona em rede, operando como práticas ritualizadas que são fios desse dispositivo. Por tudo isso, não resulta estranho que alguns alunos das séries finais do Ensino Fundamental dessa escola costumem usar camisetas com figuras de Jesus Cristo, cruz cristã e dizeres com mensagens cristãs, que são aceitas pela escola como substitutas do uniforme escolar oficial (aquele que contém o nome da instituição). Todos os dias, a constelação de elementos funciona liturgicamente como práticas que conferem/constroem/mobilizam certos sentidos para a própria vida dos indivíduos. Esse vasto sistema de práticas confere um sentido e uma ordem ao mundo. Isoladas, tais coisas, palavras e ações não fariam sentido algum.

Outro elemento litúrgico que trazemos como exemplo é o ritual da reza no início da aula. Em entrevista com a professora que ministra aulas para a turma que contempla alunos de 4 e 5 anos de idade, ela mencionou a importância de iniciar os trabalhos da tarde convidando seus alunos a "ficarem em silêncio e pedirem a proteção de Deus, para assegurar o bem estar, a paz e a tranquilidade da escola e da família". A professora alega não se tratar de ritual ligado a alguma religião específica, mas apenas um "momento de reflexão para despertar bons costumes". Todos os alunos da turma reduzem seus movimentos corporais, fecham os olhos, juntam ambas as mãos para orar e ouvem apenas a voz da professora, que faz a oração em voz mais lenta, amorosa e tranquilizadora. Os alunos, segundo ela, ficam mais calmos e prontos a começar suas atividades de escrita no caderno. A reza é um dos elementos litúrgicos que, com gestos/sons/palavras/ ritmos/etc. repetitivos, configura o dispositivo moralitúrgico envolvendo, articulando e disciplinando, com seus múltiplos tentáculos, a conduta escolar. A oração, que acalma e disciplina o corpo, também fez parte da rotina de algumas escolas da metade do século XIX, ${ }^{11}$ integrando o currículo escolar: "Os trabalhos principiarão todos os dias por uma oração cristã, curta, conveniente e composta com dignidade; encerrarse-ão com outra análoga, depois de concluída a última lição da semana: para este fim é permitido o canto" (RUEDELL, 2005, p. 38).

Esse êthos cristão se faz visível na comunidade escolar analisada, o que demonstra a confessionalidade da escola. Assim, a comunidade escolar vai sendo incitada e regulada pela rede de elementos que se dispersam e operam sob forma moral com disciplinamento litúrgico. Um dos alunos que simpatizou com nossa presença na escola nos perguntou por diversas e inusitadas vezes se acreditamos em Deus, o que gerou nele desconforto e consternação. Isso mostra como o corpo escolar necessita interrogar esse tema com frequência, incitar a falar, recomeçar a falar esse segredo, desencavar uma coisa reduzida ao mutismo e ao mesmo tempo necessária e difícil de ser dita, preciosa e perigosa de ser dita. O dispositivo moralitúgico como tecnologia de si envolve um jogo de verdade do indivíduo em relação a si mesmo, uma relação em que ele experiencia a si, observado-se, analisando-se, decifrando-se e comparando-se em relação ao outro. A tecnologia de si é composta de práticas em que os indivíduos efetuam, por conta própria e com ajuda dos outros, exame e avaliação dos próprios pensamentos e condutas, a fim de transformarem-se/corrigirem-se para atingir certo estado de sabedoria, pureza, salvação.

Outro exemplo de efeito do dispositivo moralitúrgico foi visto em uma das aulas de artes. Nessa aula, os alunos deveriam enrolar pequenas bolinhas de papel crepom de diversas cores para colá-las sobre um desenho previamente impresso pela professora. Ao buscarmos mais informações sobre esse desenho (em cuja folha dada aos alunos estava escrito "O Peçador, Tarsila do Amaral, 1925”), demo-nos conta de que, na verdade, a obra dessa artista foi intitulada por ela "O Pescador" (grifos nossos). Pecador é uma palavra do vocabulário cristão e se refere àquele que fere a moral cristã desrespeitando a lei de Deus. No corredor da escola, os dizeres lembram a todos que por ali transitam sobre humildade e perdão: esse é mais um 
exemplo de elemento que faz parte do conjunto das práticas moralitúrgicas curriculares, as quais falam e são faladas em nome do discurso cristão, construindo uma subjetivação cristã. A parede contém três frases com aconselhamentos do Papa Francisco: "O primeiro a pedir desculpas é o mais valente. O primeiro a perdoar é o mais forte. O primeiro a esquecer é o mais feliz.” Os elementos desse dispositivo pulverizam-se nas salas de aula, na sala dos professores, na sala da direção, nos corredores, enfim, em todos os espaços possíveis. A Bíblia repousa sobre a mesa das professoras como imagem que se cola e, por vezes, mistura-se aos livros, cadernos e papéis dos docentes na rotina de um ano escolar. A Bíblia é um elemento que nunca saíra de cima da mesa das professoras, apesar do rodízio de materiais deles, que se revezavam conforme o dia da semana.

Além da Bíblia, também os crucifixos são parte do dispositivo moralitúrgico, uma vez que, liturgicamente, as professoras que se dirigem ao escaninho para pegar seus materiais e a caderneta escolar (com a lista dos nomes completos de cada aluno de cada turma) olham para o crucifixo ao lado e lembram-se de sua missão/responsabilidade de, como pastoras, falar e agir em nome do cristianismo que orienta a conduta dos alunos, subjetivando-os com justificativa moral. A presença dos crucifixos e da Bíblia na sala dos professores é mais um elemento do dispositivo moralitúrgico, que marca e dá visibilidade ${ }^{12}$ a um diagrama codificado e modulador de subjetivação, o qual relaciona poder pastoral e moral cristã. As professoraspastoras devem olhar todos e cada um, cuidando para que não haja nenhum componente do grupo escolar que escape de seu zelo. "O poder pastoral é um poder de cuidado. Ele cuida do rebanho, cuida dos indivíduos do rebanho, zela para que as ovelhas não sofram, vai buscar as que se desagarram, cuida das que estão feridas" (FOUCAULT, 2008a, p. 170).

O delineamento de um sujeito cristão almejado e apresentado na escola com valor universal aparece ainda na sala da direção, onde uma série de figuras de Jesus Cristo em quadros pendurados nas paredes harmoniza-se ao conjunto de objetos diversos, sem chamar atenção de imediato. No entanto, no decorrer das nossas idas à escola, tais figuras se destacaram das paredes, colocando-se como parte de uma engrenagem operadora na construção de um modo de ser cristão. Também no chão vimos o crucifixo. Duas barras de ferro cruzadas perpendicularmente e fincadas ao solo cimentado: mais um elemento que não cumpriria nenhuma funcionalidade outra que não a de dar visibilidade a uma discursividade construtora de certa subjetividade.

Os sujeitos escolares, interpelados pela constelação de elementos - como estrelas mais ou menos visíveis - constitutivos do dispositivo moraliturgico, constroem formas de pensar e agir em cânone à discursividade, que opera hegemonicamente na escola analisada. Após a vigilância e o exame de si/dos outros/pelos outros, os sujeitos reconhecem sua culpa para que, arrependidos, possam humildemente ser corrigidos e corrigirem-se, a fim de expulsar, expurgar para fora da alma, "o mal" que lhes é interior e, enfim, libertar-se. Atividades de correção-liberação-salvação ${ }^{13}$ possivelmente são facilmente corrigíveis quando ainda não plenamente encravadas na carne, isto é, na infância e na adolescência. ${ }^{14}$

Essa purificação/transformação implica uma forma de atenção, de orientar o olhar do "exterior" (dos outros, do mundo) para o "interior" (para si), de modo atento/vigilante ao que se pensa, faz e diz, a fim de que ações corretivas sejam exercidas de si para consigo e para/com os outros. Nesse trabalho estético cristão, o que urge necessário é aparar os "erros", corrigir as "impurezas" como necessidade inflamada pela urgência da salvação de si, que diz respeito a um apelo universal (reservada, no entanto, apenas a alguns). Nessas condições, o dispositivo moralitúrgico faz ver o cristianismo como natural e inato à razão, ao bomsenso, à moralidade.

Durante o período na escola, por diversas vezes fomos surpreendidas em momentos inusitados por questionamentos de alunos acerca da religião a que nos filiamos e não menos surpreendente foi a consternação gerada ao ouvirem respostas ligadas ao ateísmo. Foucault nos lembra quão importantes são a palavra e a narração de si na/para a pastoral cristã, na árdua tarefa de fazer passar tudo por um crivo que avalia, interdita 
ou sacraliza certas palavras e decência de expressões (FOUCAULT, 1988). Em entrevista, perguntamos a uma professora se havia alunos ateus na escola. A resposta mostra a preocupação dela com uma ovelha errante que resistia ao dispositivo moralitúrgico:

Lá no nono ano, nós tivemos um aluno, o $\mathrm{M}^{\star}$, aquele... Ele não gosta... Agora eu não sei como ele tá, mas ele não gostava que falava de Deus, [...] eu fui professora dele, né, aí eu sempre dizia pra ele, eu, eu só digo assim, eu dizia pra ele assim: " $\mathrm{M}^{\star}$, eu não quero nem saber em quem tu acredita, eu só sei que na hora que tu precisar tu vai apelar por esse Ser." Porque tudo eu dizia assim: "ah... Agradece a Deus..." [e o $\mathrm{M}^{\star}$ respondia:] "que agradece a Deus, professora! Quem comprou foi o meu pai com o trabalho dele!”... [e eu respondia:] “Tudo bem, mas quem é que deu saúde pro pai?”... Isso eu sentia que irritava ele, mas assim ó, ele nunca ficou brabo comigo por causa disso porque quando eu via que tava ultrapassando, eu parava, e ele também, mas assim, a gente sente que, ao mesmo tempo em que ele se dizia ateu, mas em algum momento tu via alguma coisa assim nele, [quer dizer] que ele se apegava em [A]lguém, mesmo com aquela história que ele contava do... ai, como é que é, ..., do científico,... Do Big... Do Big Bang!... Ele contou com toda clareza aquilo, sabe? Ele deu uma aula sobre ciência pra gente! Então, assim, ó, e o pai dele é assim também, então a gente sabe que, embora a mãe e a avó quis que ele fizesse a primeira comunhão, que ele fosse à catequese, entendeu? A vó quis... Pelo pai ele não faria, porque o pai também pensa assim, então a culpa não é toda dele, né, eu sempre digo assim, ó, os nossos alunos são o que eles são em casa, e eu tenho crianças que em casa não obedecem e aqui eles obedecem, são outras crianças aqui na escola. Porque aqui eles sabem e eu sempre digo, aqui na sala quem manda sou eu. Se lá tu faz o que tu quer, problema é teu, do teu pai. Agora aqui na sala tu vai ter que me obedecer (Diário de campo, jun. 2017).

Na circunstância supracitada, a professora - como sujeito que fala em nome do discurso ${ }^{15}$ cristão ensina o que deve (e o que não deve) ser dito. A situação mostra como a professora, naquele momento, é um corpo institucionalizado que move ações e palavras em consonância ao dispositivo operante na instituição a que pertence: “O corpo é enfim a instituição 'incorporada”' (SCHMITT, 2014, p. 24).

O caráter minúsculo de mais esse exemplo mostra a preocupação dos sujeitos escolares pelos ínfimos detalhes do todo e de cada um, em uma investigação litúrgico-pedagógica diária que avalia os pormenores da vida familiar, afetiva e psicológica de cada componente do corpo escolar. Em conversa com outros professores, foi relatado como a escola dedicou constante preocupação com o aluno $\mathrm{M}^{\star}$ ao longo de toda sua vida escolar, tendo buscado argumentos nas áreas médica, psicológica e familiar para explicar as atitudes resistentes do menino. Esse aluno esteve sob observação frequente, atenta e cuidadosa, procurando não afastá-lo da escola, mas trazê-lo para mais perto, torcendo-o a falar de si mesmo e dos outros de acordo com as regras e recomendações moralitúrgicas. É interessante perceber que trazer os alunos para dentro do dispositivo moralitúrgico (como o foi para o aluno $\mathrm{M}^{\star}$ ) não significa necessariamente trazê-los para o mundo do conhecimento, pois, como vimos, a professora é ignorante em relação a alguns saberes científicos que o aluno apresenta, como a teoria científica sobre a criação do Universo, a teoria da evolução das espécies e tantas outras informações que o menino trazia à sala de aula questionando ou revidando alguns ensinamentos da escola.

A minúcia do olhar de si e para os outros, das inspeções e do controle das ínfimas parcelas da vida e do corpo, quando em um conjunto de técnicas que disciplina os pensamentos, ações, anseios etc., já há muito tempo foi analisada "na contabilidade moral e no controle político": "todo detalhe é importante, pois aos olhos de Deus nenhuma imensidão é maior que um detalhe” (FOUCAULT, 2013, p. 135). Assim, um 
dispositivo pode funcionar individualizando e disciplinando corpos a fim de que, assim solitários, voltem-se para dentro de si de modo a defrontarem-se consigo, com Deus, com a verdade.

\footnotetext{
Mais do que as velhas interdições, esta forma de poder exige para se exercer presenças constantes, atentas e, também, curiosas; ela implica proximidades; procede mediante exames e observações insistentes; requer intercâmbio de discursos através de perguntas que extorquam confissões e de confidências que superam a inquisição. Ela implica uma aproximação física e um jogo de sensações intensas [...] (FOUCAULT, 1988, p. 44).
}

O dispositivo moralitúrgico como tecnologia põe em funcionamento uma larga "dispersão dos aparelhos inventados para dele falar, para fazê-lo falar, para obter que fale de si mesmo, para escutar, registrar, transcrever e redistribuir o que dele se diz" (FOUCAULT, 1988, p. 35). Essa maquinaria traz para perto as ovelhas desviantes, interrogando-as, extraindo confissões sobre si, incitando e regulando aquilo que se deve fazer, pensar, dizer. Então, às eventuais questões feitas aos alunos - "A quem devo recorrer na hora em que preciso de socorro?”; “Quem devo agradecer por minha saúde?” -, espera-se que as respostas sejam sempre as mesmas.

À escola cabe então a função de despertar o aluno para aspectos transcendentes da existência, uma vez que governa as almas para conduzi-las a boas condutas e a valores morais universais e verdadeiros. ${ }^{16} \mathrm{~A}$ liturgia é o modus operandi que circunscreve uma maneira pedagógica de ensinar e disciplinar determinada forma de pensar e agir, que, a partir da frequência e da repetição, torna-se hábito que delineia certo modus vivendi. Em conversa com outra professora, que ministra aulas de Ciências e também de Ensino Religioso, ela relatou preocupação com questões ligadas à purificação da alma, de um "eu" capaz de discernir o bem do mal, o certo do errado, isto é, uma consciência racional e moral. Para ela, é imprescindível conhecer-se a si mesmo, entalhar-se a si para desbastar as lascas impuras (os erros, os equívocos) daquilo que é a essência (o bem, a verdade). Ela, que tem intenso envolvimento com atividades cristãs ligadas à Diocese, disse-nos considerar relevantes e úteis alguns filmes, vídeos, palestras e cursos de cunho cristão para orientar seus próprios costumes, ações e pensamentos, uma vez que trazem mensagens motivadoras para bem viver. Segundo ela, essas mensagens motivadoras orientam a maneira como deve elaborar-se a si como objeto de cuidado ético em relação a si e aos outros. Em um trabalho de investigação e escrutínio de si, vemos a professora engajada em uma luta consigo mesma em um exercício contínuo e extensivo a toda a vida.

Segundo a professora, as aulas de Ensino Religioso tratam dos valores morais que devem ser ensinados e da importância do cristianismo na função educativa da pequena comunidade. Por isso, suas aulas trazem exemplos dessas mensagens por meio de filmes para serem discutidos em sala de aula junto com os alunos. Filmes, textos e debates convocam os alunos a olharem para si, de modo que suas "imperfeições" (egoísmo, preguiça, individualismo, luxúria etc) sejam verificadas de perto, reconhecidas/analisadas/pegadas a fim de poderem ser transformadas. Nessa atividade pastoral ${ }^{17}$ de orientação do rebanho (em que a professora intervém para guiar, aconselhar e conduzir como convém), a prática de si funciona ligada a uma prática social, um tipo de exercício entre indivíduos que fazem dessa relação um modo de controle de si pelos outros, ou seja, "vem manifestamente atrelar-se às relações de si com o Outro" (FOUCAULT, 2010, p. 140).

Em uma das aulas de Ensino Religioso, o filme Deus não está morto ${ }^{18}$ foi passado para as séries finais do Ensino Fundamental. Esse filme glorifica o cristianismo, mostrando ateus e pessoas de outras religiões como arrogantes e nocivas à constituição de sujeitos bons, enquanto os personagens cristãos são mostrados como calmos, serenos, simpáticos e humildes. Algumas passagens do filme foram aqui transcritas para destacar enunciações cristãs que circulam dentro da escola: 
O universo sempre existiu. Por 2.500 anos, a Bíblia esteve certa e a ciência esteve errada./Eu vejo Jesus como meu amigo. É filho de Deus. Não quero decepcioná-lo./Fez você a imagem e semelhança d'Ele, o que significa que Ele gosta de você./Para os cristãos, o ponto fixo da moralidade, o que constitui o certo e o errado, é uma linha reta que leva direto a Deus./ Precisamos de um Deus para sermos morais, a moral ateísta é uma impossibilidade./Deus dá um manual de instrução, que é de onde tiramos nossa força, onde encontramos a esperança (DEUS..., 2014).

As enunciações trazidas no filme estabelecem forte ressonância na instituição escolar analisada, uma vez que a existência do cristianismo parece justificar a necessidade da moral cristã, assim como a moral cristã justifica a necessidade do cristianismo como caminho para a salvação. Além disso, as enunciações reverberam certas dicotomias, que ensinam um determinado entendimento do mundo separado por noções de mal/bem, certo/errado e, por extensão, os bons/os maus.

Foucault, em sua aula de $1^{\circ}$ de março de 1978, em Segurança, Território e População (2008a), diz que a moral judaico-cristã é uma criação e, em sua aula de 17 de fevereiro de 1982, em Hermenêutica do Sujeito (2010), diz que o cristianismo é uma religião que absorveu vigorosa forma moral derivada do modelo helenístico:

Foi no interior desse modelo helenístico, nem platônico nem cristão, que se formou uma certa moral exigente, rigorosa, restritiva, austera. Moral que o cristianismo de modo nenhum inventou, pois o cristianismo, como toda boa religião, não é uma moral. O cristianismo é uma religião, em todo caso, sem moral. Pois bem, foi essa moral que o cristianismo utilizou e repatriou, de início, como ponto de apoio recebido explicitamente do exterior [...] e que, a seguir, ele aclimatou, elaborou, trabalhou, mediante práticas que são precisamente as da exegese do sujeito e da renúncia a si (FOUCAULT, 2010, p. 230).

Esse modelo foi lugar de formação de uma moral que o cristianismo absorveu

para dela fazer alguma coisa que hoje equivocadamente chamamos de "moral cristâ" e que ele, ao mesmo tempo, ligou precisamente à exegese de si. A moral austera do modelo helenístico foi retomada e trabalhada pelas técnicas de si definidas pela exegese e pela renúncia a si próprias do modelo cristão (FOUCAULT, 2010, p. 231).

A formação dos sistemas de relações de saber/poder produzem e regulam os valores morais, mas, nos processos de subjetivação, é preciso mais do que apenas a existência impositiva de regras, uma vez que envolve um processo ético/estético em que "não basta que a força se exerça sobre outras forças, ou sofra efeito de outras forças, também é preciso que ela se exerça sobre si mesma [...]” (DELEUZE, 1998, p. 140).

A liturgia disciplinar entra nessa tecnologia de construção de si implicada em rituais dos mais diversos tipos. Surgiram dentro de circunstâncias históricas para definir comportamentos adequados para a superação de rudezas e "controle de gestos, delimitação da linguagem, de espaços e de situações. O rito é a forma, e a forma educa: o ritual terá atuado como um indutor pedagógico, assim como para quem testemunhava: os rituais confirmam posições e exigências" (SALDANHA, 1998, p. 47-48). Também há de se ressaltar que a prática litúrgica, como prática pedagógica, produz um modo de vida que converge à missão pastoral, a qual orienta a conduta do corpo escolar (capturando os desviantes) balizado por um código moral cristão. 
A moral cristã funciona regulando a população escolar por meio de práticas litúrgico-pedagógicas, que autorizam e legitimam certos modos de vida e movimentam, rotineiramente, cada indivíduo ao exame e ao escrutínio de si e do outro. A escola, constituída por diversos elementos heterogêneos que se repetem e redundam, no tempo e no espaço do currículo posto em funcionamento, é um processo que faz circular efeitos de poder da discursividade cristã, operando por meio de práticas litúrgico-pedagógicas - como diria Foucault "por canais cada vez mais sutis, chegando até os próprios indivíduos, seus corpos, seus gestos, cada um de seus desempenhos cotidianos" (FOUCAULT, 2009, p. 214). Significa dizer que a moral cristã organiza um modo de vida de vigilância atenta de si e dos outros para purificação/salvação de si por meio de práticas moralitúrgicas. Quando interpelado/subjetivado por esse dispositivo, o indivíduo se dobra e se põe em relação às regras - aceita e conservada como hábito em um grupo social - e se põe ligado à obrigação de pô-las em ação. Isso requer, como exercício disciplinar litúrgico, conhecer-se, controlar-se, examinar-se, permanente e detalhadamente, a si mesmo.

O dispositivo moralitúrgico produz uma relação pedagógico-pastoral cuja função moral de cuidado de si e dos outros exige um exercício contínuo de perscrutação e controle do pensar, do agir, do sentir. O padre é corriqueiramente convidado pela direção da escola a dar palestras e aconselhamentos que orientem a boa conduta da comunidade escolar. Adiante, trazemos um fragmento do diário de campo para mostrar a presença desse sujeito na escola:

O recreio havia acabado. "O padre já está esperando", diziam atordoadas as professoras. Entramos na pequena sala onde o padre teria apenas 45 minutos para cantar, tocar violão e falar de fé e de como ser um bom ser humano. Explicou que há duas coisas das quais os humanos são escravos. Perguntou quais eram. Um menina arriscou: "Jesus?" O padre, aflito, depressa corrigiu que as duas coisas eram: "pecar e morrer". Perguntou, então, o que é pecar. Um dos meninos disse: “é a Internet?” Outro disse: “são os jogos, os games?” O padre continuou falando, dessa vez sobre a importância da escola em conscientizar sobre como ser um bom cidadão para que o mundo possa ser salvo (Diário de campo, abr. 2017).

O padre, como elemento constitutivo do dispositivo moralitúrgico, aciona um conjunto de atitudes e atividades litúrgico-pedagógicas implicadas em um ambiente cuidadosamente preparado para a ascese. $\mathrm{O}$ silêncio, o respeito, a postura corporal, a manifestação de interesse dos alunos para ouvir e compreender a voz e a sabedoria do presbítero exigem um trabalho de si sobre si, isto é, de controle do corpo sobre os próprios pensamentos, instintos e ações. Esse trabalho de ascese/autoexame/autocorreção exige "a renúncia de si e o alçar-se a um estilo de pensamento e existência moral superiores” (GARCIA, 2002, p. 173).

Em um movimento ascético cristão de renúncia de si (em que o corpo deve renunciar a desejos, anseios, instintos), o si se aniquila em Deus, perde sua individualidade, para, arrependendo-se dos erros e das impurezas, aceder à outra vida, à verdade, à salvação. Nessa cultura, é preciso salvar-se para salvar os outros, pois "conhecendo-me a mim mesmo, acedo a um ser que é a verdade, e cuja verdade transforma o ser que sou, assimilando-se a Deus" (FOUCAULT, 2010, p. 173).

A salvação esteve presente no pensamento helenístico-romano, associada a um pensamento religioso. No entanto, tal noção não carregava a significação dramática cristã de acontecimento que permitisse permutar a morte pela vida, a mortalidade pela imortalidade, o mal pelo bem, esse mundo por outro mundo etc. Pelo contrário, a noção de salvação, no pensamento grego, tinha o sentido de estar conveniente e permanentemente em estado de alerta, de domínio de si para capacitar-se e tornar-se inacessível "aos infortúnios, às perturbações, a tudo o que pode ser induzido na alma pelos acidentes, pelos acontecimentos exteriores etc." (FOUCAULT, 2010, p. 166). 


\section{Considerações Finais}

Buscamos pensar sobre como uma escola põe a funcionar um dispositivo cunhado moralitúrgico como tecnologia disciplinar de controle de si composto por técnicas heterogêneas de construção, modulação e experiência de si que o indivíduo estabelece consigo mesmo. Constituído por múltiplas técnicas, o dispositivo moralitúgico põe em funcionamento uma variedade de elementos (sons, coisas, palavras, ações etc.) que, articulados, são práticas desse dispositivo. Essa maquinaria atua como currículo escolar, na medida em que organiza, seleciona e regula os conhecimentos, produzindo formas particulares de agir e pensar no mundo a partir da constituição de um si. Então, o dispositivo cria condições para que cada escolar elabore a si mesmo por meio de um jogo repetitivo pedagógico-litúrgico (com regras facultativas de conduta e engrenagem moral cristãs), com inúmeros e minuciosos procedimentos que os convocam - mobilizados pelo poder pastoral - a examinarem, confessarem faltas/erros/desejos e também transformarem-se, como atitude ascética, a partir de certos valores ético/estéticos cristãos.

Nessa maquinaria de subjetivação, os indivíduos observam-se, analisam-se, comparam-se uns aos outros e experienciam-se como sujeitos cristãos que, rotineiramente, olham/falam/ouvem Jesus, crucifixo, padre e outras técnicas exegéticas que fabricam e dão visibilidade a um determinado modo de existência - modo esse sempre móvel, sem direção, mas sensível às intensidades variáveis das linhas de forças de saber/poder que interpelam indivíduos e grupos. Na medida em que os processos de subjetivação entoam qual o modo de se constituir aluno, destacamos nossos estranhamento e resistência em relação ao modo confessional de ensino dessa escola, que se estende, como já mostrado, para além do componente curricular de Ensino Religioso. A resistência - pontual e limitada - é a não aceitação dos modos de subjetivação impostos, procurando novas combinações de formas ético-estéticas singulares como meio de experienciar-se a si mesmo. Em nosso ponto de vista, a instituição escolar constitui importante espaço, que deveria estar permanentemente aberto à multiplicidade das formas de pensar desestabilizadoras de verdades cunhadas na tradição, no dogma e na igualdade.

A capilarização da discursividade cristã (especialmente a evangélica) para dentro das instituições públicas é um tema muito atual no país, e discussões conservadoras - em temas como aborto, sexualidade, gênero, desenvolvimento de células-tronco embrionárias, relações homoafetivas, eutanásia, entre outros - circunscrevem uma unicidade de valores morais cristãos no/para o universo público (FISCHMANN, 2009; DUARTE, 2017; ALMEIDA, 2019). Se assuntos sensíveis à sociedade atravessam sempre o crivo valorativo da perspectiva cristã, então os diversos temas sociais e políticos sempre serão tratados e julgados sob essa lente. O dispositivo moralitúrgico posto em funcionamento na escola analisada interdita a abertura de outros espaços subjetivantes e vai de encontro à laicidade do Estado. Assim, pensamos ser necessário problematizar uma escola que se fecha em processos subjetivadores moralitúrgicos que interditam a passagem de outras possibilidades de pensar e agir acerca do mundo e de si mesmo.

\section{Contribuições das Autoras}

Problematização e Conceitualização: Horn GB; Loguercio RQ; Metodologia: Horn GB; Loguercio RQ; Análise: Horn GB; Loguercio RQ; Redação: Horn GB; Supervisão: Loguercio RQ. 


\section{Notas}

1. Sobre dispositivo, diz Foucault: "Através deste termo tento demarcar, em primeiro lugar, um conjunto decididamente heterogêneo que engloba discursos, instituições, organizações arquitetônicas, decisões regulamentares, leis, medidas administrativas, enunciados científicos, proposições filosóficas, morais, filantrópicas. Em suma, o dito e o não dito são os elementos do dispositivo. O dispositivo é a rede que se pode estabelecer entre estes elementos" (FOUCAULT, 2009, p. 244).

2. Denominamos "elementos" as práticas que formam os objetos de que falam. Podem ser entendidos como signos que não podem ser meramente reduzidos a uma definição exata e definitiva de si mesmos por meio de palavras que tentam fixar sua existência, traçam a existência de tudo aquilo que não são, pois a plena presença da coisa ou conceito é indefinidamente adiada (DERRIDA, 1973; SILVA, 2000).

3. A moral cristã parece ser a única que rege o Ocidente e, particularmente, o Brasil. Por isso, pensar cristianamente é quase como pensar moralmente, uma vez que seus preceitos balizam nossas condutas e pensamentos. No entanto, há instituições que enrijecem assujeitamentos e subjetivações cristãs e outras que oportunizam a existência de espaços outros para a passagem de outros fluxos constituidores de singularidades.

4. A emergência de um êthos cristão na contemporaneidade é uma atitude filosófica, uma maneira de o homem se conduzir, seus hábitos e modos de vida. "O êthos de alguém se traduz por seus hábitos, por seu porte, por sua maneira de caminhar, pela calma com que responde a todos os acontecimentos etc." (FOUCAULT, 2006, p. 270).

5. Deleuze compreende o dispositivo como um novelo ou meada com múltiplas linhas: "[...] linhas de visibilidade, linhas de enunciação, linhas de força, linhas de subjetivação, linhas de ruptura, de fissura, de fratura que se entrecruzam e se misturam [...]" (DELEUZE, 1990, p. 4).

6. A tecnologia de si envolve práticas "que permitem aos indivíduos efetuar, por conta própria ou com a ajuda de outros, certo número de operações sobre seu corpo e sua alma, pensamentos, conduta, ou qualquer forma de ser, obtendo assim uma transformação de si mesmos com o fim de alcançar certo estado de felicidade, pureza, sabedoria ou imortalidade" (FOUCAULT, 2008b, p. 48, tradução nossa).

7. A localidade possui cerca de mil moradores e a escola, aproximadamente noventa alunos (entre 5 e 14 anos de idade) e treze funcionárias (todas mulheres).

8. A escola, a igreja e o cemitério formam uma "triangulação sagrada" na comunidade, três loci, praticamente equidistantes e muito próximos entre si, que estabelecem rituais consagrados e repetitivos.

9. Prática discursiva "é um conjunto de regras anônimas, históricas, sempre determinadas no tempo e no espaço que definiram, em uma dada época, e para uma área social, econômica, geográfica, ou linguística dada, as condições de exercício da função enunciativa" (FOUCAULT, 1986, p. 136). As práticas não discursivas podem ser entendidas como as instituições, os acontecimentos políticos, os processos econômicos, e tantas outras práticas. "Tais domínios, porém, não podem ser vistos como 'expressão' de um discurso, nem como seus determinantes, mas como algo que faz parte de suas condições de emergência” (FISCHER, 2001, p. 216).

10. O dispositivo moralitúrgico é pedagógico na medida em que ensina informações, as quais devem passar por um filtro moral cristão - organizado no/pelo corpo escolar - que seleciona, categoriza, organiza, avalia e hierarquiza quais conhecimentos são mais ou menos importantes, assim como de que forma devem ser tratados, isto é, como o corpo deve sentir, pensar, falar e agir em relação aos assuntos abordados. 
11. Regulamento do Rio Grande do Sul, de 15 de junho de 1855 , art. $15, \$ 9^{\circ}$.

12. As visibilidades e dizibilidades são derivadas do saber de uma formação histórica, a qual "vê e faz ver tudo o que pode, em função de suas condições de visibilidade, assim como diz tudo o que pode, em função de suas condições de enunciado" (DELEUZE, 2013, p. 68). As formas de conteúdo e expressão das dizibilidades não correspondem imediatamente a unidades linguísticas (palavra, frase, proposição, ato de linguagem) e nem as formas de conteúdo e expressão das visibilidades se confundem com elementos visuais. "As visibilidades não são formas de objetos, nem mesmo formas que se revelariam ao contato com a luz e nem com a coisa, mas formas de luminosidade, criadas pela própria luz e que deixam as coisas e os objetos subsistirem apenas como relâmpagos, reverberações, cintilações" (DELEUZE, 2013, p. 62).

13. A produção de si, no modelo cristão, “impõe-se sobre o fundo de erros, de maus hábitos, de deformação e de dependências estabelecidas e incrustradas, e que se trata de abalar. Correção-liberação, bem mais que formação-saber: é nesse eixo que se desenvolverá a prática de si, o que evidentemente, é fundamental” (FOUCAULT, 2010, p. 86).

14. Interessante notar que os escolares foram olhados com preocupação e vigilância em vários momentos da história. "O sentido da moralidade aprofunda-se entre o fim da segunda infância e o começo da adolescência, ou seja, dos 13 aos 15 anos. Trata-se do sentido da responsabilidade e do seu complemento, o da culpabilidade, que permite a justa concepção do pecado, atingindo o domínio das nossas relações com Deus” (WILLOT, 1969, p. 312).

15. Um discurso é um conjunto de enunciados de um determinado campo de saber que existe como práticas. Os discursos (religioso, pedagógico, médico, científico, jurídico etc.) não existem sozinhos, mas se cruzam, associam-se, disputam legitimidade. Assim, o discurso religioso pode se associar ao discurso pedagógico, por exemplo. Contudo, os discursos, embora tenham instâncias e delimitações diferentes, comunicam-se e encontram superfícies de emergência ou condições de possiblidade para definir aquilo de que falam, ou seja, para fazer aparecer um determinado objeto, tornando-o nomeável e descritível (FOUCAULT, 1986).

16. O cristianismo funciona entrelaçado a uma moral que aprova certos tipos de comportamentos e condena outros, demarcando um entendimento de Verdade essencial, natural, já dada desde sempre.

17. O poder pastoral cristão problematizado por Foucault é considerado o início de um modo de governamentalidade. Para abordar o problema do Estado e da população, Foucault mostra como a governamentalidade do Estado nasceu com a pastoral cristã, sob a forma da direção da consciência e das almas (FOUCAULT, 2008a).

18. DEUS..., 2014.

\section{Referências}

ABADÍA, Ó. M. Michel Foucault: de la épistemè al dispositif. Revista de Filosofía de la Universidad de Costa Rica, San José, v. XLI, n. 104, p. 27-37, jul./dec. 2003. https://orcid.org/0000-0002-3992-7933

ADAM, J. C. Ritos cristãos. História, teologia e prática. São Leopoldo: Sinodal/EST, 2010.

AGAMBEN, G. O que é um dispositivo? Outra Travessia, Florianópolis, n. 5, p. 9-16, 2005. https://doi. org $/ 10.5007 / \% 25 x$

ALMEIDA, R. Bolsonaro presidente: conservadorismo, evangelismo e a crise brasileira. Novos Estudos CEBRAP, São Paulo, v. 38, n. 1, p. 185-213, 2019. https://doi.org/10.25091/s01013300201900010010 
DELEUZE, G. ¿Que és un dispositivo? Barcelona: Gedisa, 1990. Disponível em: https://escolanomade. org/2016/02/24/deleuze-o-que-e-um-dispositivo/. Acesso em: 15 ago. 2019.

DELEUZE, G. Conversações. Rio de Janeiro: Editora 34, 1998.

DELEUZE, G. Foucault. São Paulo, Brasiliense, 2013.

DEUS não está morto. Direção: Harold Cronk. EUA: Graça Filmes, 2014. 1 DVD (113min.).

DERRIDA, J. Gramatologia. São Paulo: Perspectiva, 1973.

DUARTE, L. F. D. Valores cívicos e morais em jogo na Câmara dos Deputados: a votação sobre o pedido de impeachment da Presidente da República. Religião \& Sociedade, Rio de Janeiro, v. 37, n. 1, p. 145-166, 2017. https://doi.org/10.1590/0100-85872017v37n1cap08

FISCHER, R. M. B. Foucault e a análise do discurso em educação. Cadernos de Pesquisa, São Paulo, n. 114, p. 197-223, 2001. https://doi.org/10.1590/S0100-15742001000300009

FISCHMANN, R. A proposta de concordata com a Santa Sé e o debate na Câmara Federal. Educação \& Sociedade, Campinas, v. 30, n. 107, p. 563-583, maio/ago. 2009. https://doi.org/10.1590/S0101-73302009000200013

FOUCAULT, M. A arqueologia do saber. Rio de Janeiro: Forense, 1986.

FOUCAULT, M. História da sexualidade I. A vontade de saber. Rio de Janeiro: Edições Graal, 1988.

FOUCAULT, M. História da sexualidade 2. O uso dos prazeres. Rio de Janeiro: Edições Graal, 2001.

FOUCAULT, M. A ética do cuidado de si como prática da liberdade. Ditos \& Escritos V. Ética, sexualidade, política. Rio de Janeiro: Forense Universitária, 2006.

FOUCAULT, M. Segurança, território e população. Martins Fontes: São Paulo, 2008a.

FOUCAULT, M. Tecnologías del yo. Y otros textos afines. Buenos Aires: Paidós, $2008 \mathrm{~b}$.

FOUCAULT, M. Microfísica do poder. Rio de Janeiro: Edições Graal, 2009.

FOUCAULT, M. Hermenêutica do sujeito. Martins Fontes: São Paulo, 2010.

FOUCAULT, M. Vigiar e punir: nascimento da prisão. Petrópolis: Vozes, 2013.

FRAGO, A. V.; ESCOLANO, A. Currículo, espaço e subjetividade: a arquitetura como programa. Rio de Janeiro: DP\&A, 2001.

GARCIA, M. M. A. Pedagogias críticas e subjetivação: uma perspectiva foucaultiana. São Paulo: Vozes, 2002.

GIUMBELLI, E. Símbolos religiosos em controvérsias, São Paulo: Terceiro Nome, 2014.

LARROSA, J. Tecnologias do eu e a educação, Petrópolis: Vozes, 1994.

LÉVI-STRAUSS, C. O pensamento selvagem. Trad. Tânia Pellegrini. Campinas: Papirus, 1989.

LORENZETTI, M. A. G. Educação musical na Igreja Católica: reflexões sobre experiências em contextos da grande Porto Alegre/RS. 2012. Monografia (Licenciatura em Música) - Instituto de Artes, Universidade Federal do Rio Grande do Sul, Porto Alegre, 2012. 
RUEDELL, P. Trajetória do ensino religioso no Brasil e no Rio Grande do Sul. Legislação e prática. Porto Alegre/Canoas: Sulina/Unilasalle, 2005.

SALDANHA, N. Ética e história. Rio de Janeiro: Renovar, 1998.

SCHMITT, J.-C. O corpo, os ritos, os sonhos, o tempo: ensaios de antropologia medieval, Petrópolis: Vozes, 2014.

SILVA, M. R. Navegação Lacustre Osório-Torres. Porto Alegre: D.C. Luzzatto, 1985.

SILVA, T. T. A produção social da identidade e da diferença. Identidade e diferença: a perspectiva dos estudos culturais. In: SILVA, T. T. (org.). Stuart Hall, Kathryn Woodward. Petrópolis: Vozes, 2000.

SILVA, T. T. Documentos de identidade. Uma introdução às teorias de currículo. Belo Horizonte: Autêntica, 2010.

VALDUGA, G. Paz, Itália, Jesus: uma identidade para imigrantes italianos e seus descendentes - o papel do jornal Correio Riograndense (1930-1945). Porto Alegre: EDIPUCRS, 2008.

WILLOT, A. Educadores cristãos através da história. São Paulo: Atlântida, 1969.

\section{Sobre as Autoras}

Graciela Bernardi Horn é Licenciada em Biologia, Mestre em Ecologia e Doutora em Educação em Ciências pela Universidade Federal do Rio Grande do Sul. Atuou por dez anos como docente em escolas públicas e privadas do estado do Rio Grande do Sul (2006-2016). Integrante do grupo de pesquisa Núcleo de Estudos em Currículos e Subjetividades, coordenado pela Professora Doutora Rochele de Quadros Loguercio.

Rochele de Quadros Loguercio é Professora do Programa de Pós-graduação em Educação em Ciências da Universidade Federal do Rio Grande do Sul (UFRGS). Pós-doutora em Filosofia pela Universidad Complutense de Madrid. Doutora e Mestre em Educação em Ciências pela UFRGS. Presidenta da Associação Brasileira de Pesquisa em Educação em Ciências, na gestão 2019-2021. Coordenadora do grupo de pesquisa Núcleo de Estudos em Currículos e Subjetividades. 